\title{
Working with Socially Vulnerable Children in Day-Care Institutions - What Works?
}

\author{
Kirsten Elisa Petersen \\ Department of Education, Aarhus University, Denmark
}

\begin{abstract}
This article focuses on the importance of the daycare institution as part of the overall educational program for all children and adolescents in Denmark. In Denmark, as well as the other Nordic countries, virtually all children attend day-care, before starting school. However, it is still relatively new to explore the importance of the pedagogical efforts in the day-care institution as early intervention that may help to support socially vulnerable children and their social, emotional and cognitive development in order to increase this group of children's chances in relation to schooling and education. The article is based on empirical data from a recently completed research study that has explored the day-care institution's interventions and impact on socially vulnerable children and parents, and thus identified how the pedagogical work helps to improve socially vulnerable children's life chances.
\end{abstract}

\section{Introduction}

In recent years, a significant focus on the daycare institution's pedagogical work, function and impact on children's learning and development prior to schooling has increased. Pedagogues, politicians as well as researchers are all engaged in how the day-care institution may serve in relation to children's learning, socialization and development before school in a Danish as well as Nordic context [5] [35] [36] [37]. ${ }^{1}$

It is not new knowledge either in an international or Danish context that the day-care institution has an impact on children's learning and development. Additionally, the day-care institution is considered as (first) part of the overall Danish educational programme within sociological research of education and thus to a great extent important for creating opportunities for children's learning,

\footnotetext{
${ }^{1}$ In Denmark virtually all children attend day-care facilities before starting school. Recent statistical data show that 96 percent of all Danish children attend day-care facilities before starting school. In Denmark we have two types of ECEC-services, respectively family day-care or nursery for the youngest children and kindergarten for children aged 3-5 years both administrated by local municipalities. Most ECEC-services in Denmark are currently organized as age-integrated institutions holding children of different age groups, e.g. 0-2-year-old, 3-5-year-old. Children age 6 years or more are often in after school care.
}

development and socialization in relation to school and also for acquiring social norms and values [5] [13] [24] [25] [39] [41].

A significant focus on the day-care institution's impact on socially vulnerable children and their development has occured in recent years. And through the day-care institution's pedagogical efforts opportunities are explored in order to increase the children's school readiness, language development and to prevent a childhood affected by vulnerability.

A number of social political laws and adoptions, especially the Law about Learning Plans and Law on Day-Care Offers, indicate just how important the day-care institution has become as early preventive intervention in relation to socially vulnerable children [34] [50] [51].

Thus, for the first time writing a distinctive change in relation to the day-care institutions societal tasks that work through early pedagogical interventions in order to prevent children from growing up affected by negative social heritage. Thus, the Law on Day-Care Offers $\S 1$, section 3 emphasize; 'to prevent a negative social heritage and exclusion by integrating the pedagogical offers as a part of the total offers from the local authorities for children and adolescents and part of the preventive and supportive intervention aimed at children and adolescent in need of special effort...' [50].

However, the day-care institutions in Denmark do not have the same working conditions to perform the daily pedagogical work, on the contrary, the differences between institutions distributed on the Danish map are significant. One explanation for these differences focuses in particular on the pedagogues' perception of whether they have socially vulnerable children in the day-care institution or not [41] [43]. When looking at the Danish map and the existing day-care institutions, extensive differences between them appear and it turns out that not all day-care institutions work with socially vulnerable children in their daily work. Thus, the differences are identified on the basis of whether the pedagogues consider the day-care institution to have socially vulnerable children, first identified by Christensen, who elucidates that some day-care institutions consider themselves having several socially vulnerable children, while others never encounter a socially vulnerable child [8]. 
The concept of social segregation covers in this context the unequal distribution of socially vulnerable children which is justified in the way municipalities distribute children in the day-care institutions; if the child lives in a socially deprived residential area, it automatically belongs to the daycare institution nearby. An important aspect in this context is the fact that Christensen points out that the day-care institutions which hold several socially vulnerable children not necessarily have been provided extra resources [8].

This division between the day-care insitutions that have socially vulnerable children and those who have not, has been extended by Petersen who has examined the day-care institution's work with socially vulnerable children, and in this connection identified three types of day-care institutions: type A, $\mathrm{B}$ and $\mathrm{C}$ which in no way refers to $\mathrm{A}$ being better than B or C, but is merely letter categories, emphasizing the differences in the types of institutions on the basis of the pedagogues experiences and assessments of their tasks and working conditions [41] [43].

A type A institution is an institution located in areas with single-family houses, and where the pedagogues estimate that there often are no socially vulnerable children.

A type B institution is an institution which is typically located on the border between the areas of single-family houses and areas with social housing, and thus receives children from both areas. This type of institution holds children assessed as socially vulnerable as well as normal, well-functioning children. Also identified in this type B institution is a group of children, a grey area group, who are children whom the pedagogues periodically may be concerned about and thus watch carefully.

Type $\mathrm{C}$ institution is on the other hand the type of day-care institution, which is located in the center of social housing, and in some cases also in the socalled ghetto areas ${ }^{2}$, and mainly comprises children who in various ways are estimated to be socially vulnerable. In this type of institution, the majority of the children are also children with different ethnic backgrounds than Danish ${ }^{3}$ [24] [25] [41] [43].

\footnotetext{
${ }^{2}$ The government's ghetto report clarifies the following categories for the term ghetto: a residential area that has a population of at least 1,000 and at least 40 percent of the inhabitants aged 18-64 years are outside the labor market. Or has a population of a least 5,000 and at least 30 percent of the inhabitants aged 18-64 years are outside the labor market. Often these areas have an overrepresentation of inhabitants with immigrant background, but it is not a condition for getting listed. Source: the website for the Ministry of Social Affairs.

3 The 'government's strategy against ghettos' [18] in particular emphasizes the importance of children and adolescents growing up in these environments and the implicated exclusion mechanisms - merely from growing up in these residential areas which in general are affected by many transits (change of residence), parents lack of affiliation to the education and labor
}

From a recently completed research project ${ }^{4}$ type $\mathrm{C}$ day-care institutions located in ghetto-like residential areas have participated in order to develop new and research-based knowledge about the daycare institution's importance for socially vulnerable children and families in general and in particular the importance of early pedagogical interventions in relation to socially vulnerable children's development [24] [28].

A number of factors in the day-care instititution are explicit, as the majority of the children in the day-care institution has a different ethnic background than Danish, and are primarily refugees or children of immigrants from Arab or Middle Eastern countries. Several of the children do not yet speak or only insufficiently the Danish language, and several of the parents do not speak Danish at all, and they have no knowledge of how to contact the doctor when their child is ill, or how and where to get help with other practical everyday problems. Nowhere else in Denmark than in these ghetto areas one will find such a concentration of children and families with different ethnic background than Danish why these conditions are quite unique for the day-care institutions physically located in ghetto areas [1] [2] [6] [7] [16] [26] [30] [31] [38]. Through the period from September 2011 to September 2012 and the period 2012-2014 the research project has followed children and adults in four day-care institutions located in ghetto areas in Denmark. Methodically, the project has collected data from observations of pedagogues and children in their everyday life, interview with the pedagogical personnel and parents, and parts of the project's results are presented in the following and help to illuminate the day-care institution's importance for increasing socially vulnerable children's life chances.

\subsection{Who are the Socially Vulnerable Children?}

In Danish research within the pedagogical and social political area a variety of concepts are used that seek to analyze, understand and implement interventions targeting a particular group of children. Concepts such as children at risk, children with special needs, socially vulnerable children and children in and/or with difficulties are often mentioned. These concepts provide a great ambiguity

market, poverty as well as a high concetration of inhabitants with different ethnic background than Danish.

${ }^{4}$ The research project consists of two processes. One project has elapsed in the period from September 2011 to September 2012 and has been financially funded by the PUF, FOA's Development Fund. A report of the project's theoretical and empirical results has been published [24]. The second project has elapsed in the period 2012-2014 and has been financially funded by BUPL's Research Fund. The project has recently been completed. A report stating the theoretical and empirical results of the project is about to be published. 
in relation to determine when a child is at risk or have special needs. It is quite difficult to clarify regardless of whether the presentation comes from research, the pedagogical practice or the political area. Thus, important to bear in mind that the interpretations of this group of children are constantly changing in response to political, historical, economic and cultural changes.

Within the research field related to socially vulnerable children an account for why one concept is chosen over the other is often met. In Denmark the term children at risk is often used, which points to the risk research, with focus on the fact that children who live with a number of risk factors in their upbringing in particular are socially vulnerable in their lives in various areas [46] [47]. Rutter emphasizes the way in which childhood life may come across a number of risk factors and a number of protective factors [46] [47]. These factors have an impact on each other in very complex interactions, in which it is difficult to specify the factors leading to assist the child in life, and the factors that impede the child's development. The complex interaction refers to the fact that it is difficult to illustrate exactly how the interaction between the number of risks and number of protective factors helps some children to succeed in life despite numerous risk factors. In other words: why do some children manage their childhood and adolescence despite a difficult upbringing, while others do not?

The risk research is engaged in capturing the causes and symptoms of difficult and stressful childhood conditions. At the same time the consequences of the difficult childhood conditions are analysized - and not less important - the risk research also engage in resilience [46]. Resilience is translated from the English word resilience and is a concept that attempts to explain why some children and adolescents in spite of their difficult upbringing still manage to cope with their lives. Resilience is a concept that includes the child or young person's positive self-image. Resistance to stress is associated in particular with the following three conditions:

1) The child's confidence in his own abilities both cognitively and socially

2) The ability to assess and predict the situation and make strategic choices

\section{3) Support in your network [49].}

In recent decades research abroad and in Denmark has used this risk perspective in theoretical and empirical analyses of socially vulnerable children and adolescents - also known as risk studies. In practice this perspective identifies a list of stress factors such as stressful living conditions, parents with mental illness and addiction problems, and that these stress factors may be followed over time, e.g. in longitudinal studies such as the study of children placed in care [11] [12].

In recent years extensive research in relation to the day-care institution's interventions and importance aimed at socially vulnerable children in Denmark has also been conducted, and this has contributed to several definitions of the concept of socially vulnerable children, among others Jensen et al. [22] [23]. Within this research the concept of socially vulnerable children is defined as children who 'are or likely to be at risk in the institution, school, education, and later in the society as a result of growing up in socially stressful conditions, i.e. conditions reflected by poverty, parent's unemployment, low or no education or parents on transfer income and/or difficult divorces' [23].

Jensen et al. emphasizes that children, who grow up under socially deprived conditions, are at risk of being socially vulnerable or marginalized, and this marginalization process points out that this group of children and adolescents find it harder to acquire the skills required in order to handle their childhood and youth in relation to the day-care institution, school and education [23].

When the concept of socially vulnerable children are identified, it is also important to clarify how and in what ways the childhood life of this group of children seems to emerge. A number of Danish research studies have identified the causes as well as signs of severely difficult childhood conditions and in this context these can be used to display how vulnerability emerges in childhood life. Thus, Christensen clarifies a number of difficulties which can be identified in relation to socially vulnerable children [9]:

- Children who have conflicts with peers

- Children in families with separation and divorce, where the mother has been abused

- Children in families where the mother says that she feels depressed

- Children who speak the language of Danish poorly, including children who are not happy to go to school.

On a general level the international research on socially vulnerable children also points out that signs of vulnerability are illustrated through problem descriptions; emotional difficulties, problems with behavior, cognitive difficulties and delays in development related to language, comprehension and concentration. In addition, socially vulnerable children so to speak enter the school life with social, emotional and cognitive problems. 
In the international research children's vulnerability is described in three main psychological areas: ${ }^{5}$

- Social and emotional signs referring to problems such as low self-esteem, aggressive behavior and low impulse control [14] [29] [32] [45].

- Signs related to learning involving delayed language development, cognitive problems in general as well as problems related to schooling for socially vulnerable children. Thus, a number of studies identifies a correlation between the child's vulnerability and learning difficulties [10] [53] [55].

- Signs of interaction refer to the interaction between the child and parents and include signs of vulnerability in relation to the child's interaction with parents/other children/other adults. Thus, a number of studies identify a connection between parents' social and economic status in relation to the child's difficulties which presumably are crucial to the child's development [3] [15] [17] [33] [44].

These difficulties in relation to socially vulnerable children which move within the socioemotional area, the learning area and in relation to the child's interactions with its environment, are all signs of vulnerability identified through studies with a focus on the day-care institution's work with socially vulnerable children in an international perspective. In this context they help to identify how this group of children seems to emerge in the institutional contexts in which young children find themselves before starting school.

\subsection{What do we Know about the Day-Care Institution's Impact on Socially Vulnerable Children?}

The fact that the day-care institution holds socially vulnerable children is certainly not new knowledge in a Danish context. However, it is only within the last 10 years that the field of research has had a focus on how and in what ways the day-care institution and the professional pedagogues are conducting the work with this group of children [40]. The reason why this research focus has only existed witin the last 10 years is difficult to explain precisely. However, in recent years a number of research studies have emerged which in various ways

\footnotetext{
${ }^{5}$ The three main psychological areas was first identified through international research studies in the review 'The day-care institutions' importance for socially vulnerabe children - a research review' [40], in which the psychological understandings and main areas are elaborated.
}

and with different theoretical and methodological perspectives have had a focus on the day-care institution's work and opportunities to support socially vulnerable children's development [19] [20] [21] [23] [24] [25] [26] [27].

Broadly viewed across the research field in a Danish context, the research studies of the day-care institution and work with socially vulnerable children can be divided into a functional and a societal approach [41] [43]. The functional approach compiles all studies that in various ways explore how the day-care institution in its current pedagogical form may function as a tool to break a childhood reflected by negative social heritage or otherwise to assist socially vulnerable children. In general the results from these studies point out the fact that the day-care institution possess opportunities to support socially vulnerable children, but also that there are some limitations in relation to economic and personnel resources, but also limitations in relation to pedagogy, which to a greater extent is organized to serve most children, but not necessarily has the capacity for children with difficulties - quite the contrary [8] [19] [20] [21] [22] [23].

The societal approach holds a number of research studies which do not necessarily have an explicit focus on socially vulnerable children, but a focus on children's childhood life in the day-care institution's everyday life in a modern society, often on the basis of sociological theories. Through a study of the lives of children in day-care on the basis of Bourdieu's theory, Palludan has illuminated socio-cultural differences and similarities, which are assumed to take place through the socialization scene of the daycare institution [4] [39]. These studies indicate that ethnic Danish girls who comes from a middle class background handle the kindergarten's requirements best, while boys with different ethnic background than Danish, and whose parents are unemployed, is the group of children who find the day-care institution most difficult: "The hierarchical structures of domineering of society can, in a complex form, be recognized in the patterns of hierarchy which are established and maintained in the pedagogical landscape...." [39].

Common to the studies within the societal perspective are the fact that they engage in children who in different ways fail to be heard or can not handle the requirements and norms of the everyday life in the day-care institution. The fact that some children are unable to meet these requirements and norms do not necessarily involve children at risk, but in usage of different theoretical perspectives it is possible to identify that the day-care institution in the current form does increase some children's skills, while other children find it far more difficult to handle the settings, rules and norms of their everyday. 
If we turn to international research we find a number of interesting studies through the last decades that have explored the day-care institution's impact on socially vulnerable children. However, these study results are difficult to apply to a Danish context because of several differences between countries both politically, socially, culturally, but most certainly also in the way the day-care institution is constructed and how the pedagogy is performed. However, this should not put a limitation to the possibility of inspiration, especially in relation to regarding the day-care institution as an extremely important area of children's lives, and as the first part of children's encounter with the overall schooland education system.

A study from England have through recent years been exploring the day-care institution's impact on socially vulnerable children [48] [52]. The results from this survey show a difference in children's cognitive and social development in relation to whether the children attend day-care before schooling, or whether they are taken care of at home. Children who attend a day-care institution show significant better test results in term of social and cognitive development, while the children who were taken care of at home also mainly appeared to have domestic relations reflected by the mother's unemployment, lack of education, low income and with a different ethnic origin than English

Another interesting study is a Dutch study which has organized pedagogical efforts in the day-care institution, specifically in relation to socially vulnerable children [54]. The purpose of the pedagogical efforts in the day-care institution and preschool is to support socially vulnerable children's development, and thus try to improve children's chances in the long run. The planned learning program includes a very detailed process that includes games as well as learning activities based on specific stages of development in the children. The study results indicate that early intervention based on participation in the day-care institution with a planned learning program is important for socially vulnerable children, particularly in relation to their linguistic and cognitive development. In addition, the importance of a low pedagogue-child ratio as well as an organized "tutor program" to support the most socially vulnerable children are pointed out. The tutor program consists of intensive support from an adult throughout the day-care process for those children who are considered to have the most difficulties.

In conclusion, Danish as well as international studies all emphasize however in different ways the day-care institution's impact on children's development and school readiness, and several of the studies also point out the day-care institution's challenges in relation to socially vulnerable children and raise factors of importance as well as factors which hold difficulties.

\section{Distinctive Focus Areas in the Day- Care Institution to Prevent Vulnerability}

First of all, the location of a day-care institution in a socially deprived residential area, called a type $\mathrm{C}$ institution, strongly suggest that the pedagogical personnel has a wide range of very specific tasks, which to a great extent differ from the day-care institutions located in other types of residential areas in Denmark [41]. These tasks have focus on specific tasks in relation to care for socially vulnerable children as well as a comprehensive family work, where the aim is to help parents in exposed situations and to support in relation to upbringing and development of the children [24] [28].

These two findings; the specific care tasks and family work is the most significant results from the recently completed research project. These results were revealed significantly in the data, and it is these data which to a great extent contribute to distinguish the day-care institutions located in ghetto-like residential areas from other day-care institutions, which are not located in these areas. These results also help to maintain the assumption that the daycare institution has a very specific impact and function in relation to socially vulnerable children's lives and can contribute to promoting children's development.

The specific care tasks relate especially to the pedagogues' understanding of the children and the knowledge they have acquired about the children's family circumstances. On this basis a number of pedagogical interventions are initiated with a focus on providing care for the children in their everyday lives.

The understandings of the children's vulnerability and their particular difficulties are indeed consistent with the research-based knowledge as illustrated earlier in this article. Thus, we are dealing with children who are socially vulnerable in several social, emotional and cognitive areas, but also children who are considered to be exposed to neglect, who lack solid food and clothes that fit the season and who are left to their own devices much too early.

The care work in the pedagogical everyday are presented as many of the children need a little extra help before they can even begin to play. This extra may be comfort, food, clean clothes, or to be with an adult most of the day and sit on your lap or hold your hand. It may also be tasks that focus on helping the individual child to enter into play with other children, or to play in ways that are far more appropriate for the individual child.

Naturally, many of these care tasks can be found in several day-care institutions across the country, 
but the decisive factor is the pedagogues' emphasis on the extent and significance of caring, often an extent that at the same time are considered to consume time from the general pedagogical work in relation to learning plans and school preparation. Among the pedagogical personnel a general experience show that the care work in relation to children's physical and mental well-being takes up so much time that it is difficult to manage the other tasks during the day, and that this is quite difficult to change, given that many of the children have a hard time.

The family work in the day-care institution is to a great extent also about the pedagogues' understanding and knowledge of the families who live in the local area. Often the families have had children in the day-care institution for several years, and several of the pedagogues explain how they have known families who have had 4 and 5 children in their particular day-care institution. This results in an intensive knowledge of these families, as the period between the first and last child attending the institution may be between 6 and 10 years.

In a type $\mathrm{C}$ day-care institution parents play a big part of the everyday life in the institution, and the pedagogical personnel emphasize that they spent just as much time on parents as the children. The work is not always unproblematic and the pedagogues explain that in the professional work it is important to bear with parents, that one must be prepared for outbreaks or inappropriate reactions from parents, that it may be difficult to communicate with parents, and that one can feel powerless when you can not help stressful parents. The pedagogical personnel also emphasizes that the problems with parental relationship especially relates to the fact that the parents find it difficult to put themselves in the place of others, that they have different views on how to set limits for children, that parents are not demanding enough or need extra contact, that they may become angry or extra worried.

But the work in relation to parents is also about a number of social initiatives conducted by the pedagogues, i.e. assistance to socially vulnerable families in many areas, that lies significantly beyond the traditional understanding of the general pedagogical work in the day-care institution. This may be evening activities with the mothers in the day-care institution, in order for them to have a place to be with their children and the pedagogical personnel. It may be home visits to the families and assistance to a number of practical tasks such as contacting the Immigration Service, doctor, social worker, etc., when parents are unable to manage this. It may also be an invitation to visit and stay in the day-care institution in order to create a comfortable place for parents and a place where they can get advice and guidance in relation to upbringing and everyday issues.

\section{Concluding Remarks}

The fact that a day-care institution is located in a socially deprived residential area seems to have a particular task and function in relation to socially vulnerable children and families who live in these residential areas. The specific tasks and functions relate to a number of additional tasks which concern support and help to socially vulnerable families in their everyday lives. These tasks will have a crucial impact on the opportunities that are present in the day-care institution in relation to the general pedagogical efforts conducted in a Danish day-care institution.

Several of these additional tasks concern a special focus on family work and caring for socially vulnerable children.

These findings indicate that it is important to develop knowledge about the significance of the daycare institution's work in the socially deprived residential areas, including developing early preventive intervetions in working with socially vulnerable children and families.

\section{References}

[1] Andersen, H.S. (2006a). At bo sammen eller spredt? Etniske minoriteters boligønsker og motiver for bosatning. ('To live together or spread? - Ethnic minorities housing desires and motives for settlement'). København: Statens Byggeforskningsinstitut.

[2] Andersen, H.S. (2006b). Undersøgelse af til- og fraflytning $i$ tre multietnisk boligområder. (Study of moving in and out in three multi ethnic residential areas'). København: Statens Byggeforskningsinstitut.

[3] Baxter, A., \& Kahn, J.V. (1999). 'Social Support, Needs and Stress in Urban Families with children enrolled in an early Intervention Program'. Infant-Toddler Intervention. The transdisciplinary Journal, vol. 9(3), 239257.

[4] Bourdieu, P. (2004), Af praktiske grunde. ('For practical reasons'). København: Hans Reitzels Forlag.

[5] Brostrøm, S. (2004). Signalement af den danske daginstitution - Unders $\phi$ gelser, resultater og refleksioner. ('Description of the Danish kindergarten - Studies, results and reflections'). København: Danmarks Pædagogiske Universitet.

[6] Børresen, S.K. (2002). Boligmassig segregering. Hvad er årsagen til, at flygtninge og indvandrere bor koncentreret $i$ de belastede boligområder? ('House segregation. For what reason does refugees and immigrants live concentrated in the deprived residential areas'). AMID. Working Paper Series 14/2002.

[7] Børresen, S.K. (2008). Konflikter i boligområder opfattelser og håndtering. ('Conflicts in residential areas - 
perceptions and handling'). Statens Byggeforskningsinstitut, Aalborg Universitet. 5-7.

[8] Christensen, E. (1996). Daginstitutionen som forebyggende tilbud til truede børn - en undersøgelse af 796 daginstitutioner. ('Day-care and preventive services for children at risk - a study of 796 day-care centers'). København: Socialforskningsinstituttet.

[9] Christensen, E. (2006). Opvakst med sarlig risiko indkredsning af børn med behov for en tidlig forebyggende indsats. ('Growing up at particular risk - identification of children in need of early preventive intervention'). København: Socialforskningsinstituttet.

[10] Conroy, M.A., \& Brown, W.H. (2004). 'Early Identification, Prevention and Early Intervention with Young children at risk for Emotional or behavioural disorders: Issues, Trends, and a call for action.' Behavioral Disorders, May 2004, 29,(3), 224-236.

[11] Egelund, Tine et al. (2004). Små børn anbragt uden

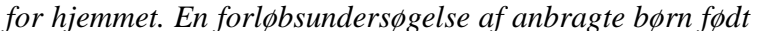
$i \quad 1995$ ('Young children placed outside home. A longitudinal study of children born in 1995 and placed in care'). København: Socialforskningsinstituttet.

[12] Egelund, Tine et al. (2008). Anbragte børns udvikling og vilkår. Resultater fra SFI's børneforløbsundersøgelse af årgang 1995. ('Children placed in care and their development and conditions. Results from SFI's longitudinal study of 1995'). København: SFI, Det Nationale Forskningscenter for Velfærd.

[13] Ellegaard, T. (2004), Et godt børnehavebarn? Daginstitutionens kompetencekrav og hvordan børn med forskellig social baggrund håndterer dem. ('A good preschool child? Day-care institution competence requirements and how children from different social backgrounds handle them'). Ph.d.-afhandling. Forskningsprogrammet Børns vilkår og velfærd i senmoderniteten. Psykologi, Roskilde Universitetscenter.

[14] Fantuzzo et al. (1995). 'Assessment of preschool play Interaction behaviors in young low-income children: Peer Interactive Play Scale.' Early Childhood Research Quaterly, 10, 105-120.

[15] Gross, D. et al. (2003). 'Parent Training of Toodlers in Day Care in Low-income Urban Communities.' Journal of Consulting and Clinical Psychology, 2003, vol. 71(2), 261-278.

[16] Hansen, K.E. et al. (2010). Om at bo sammen i et multietnisk boligområde. ('About living together in a multi ethnic residential area'). Statens Byggeforskningsinstitut.

[17] Hubbs-Tait, L. et al. (2002). 'Relation of Maternal Cognitive Stimulation, Emotional Support, and intrusive Behavior during Head Start to Children's Kindergarten Cognitive Abilities'. Child Development, January/February, vol. 73(1), 110-131.

[18] Integrationsministeriet (2004). Regeringens strategi mod ghettoisering. (Government's strategy against ghettos').
[19] Jensen, B. et al. (2003). Daginstitutionen som instrument til at bryde social arv - hvad ved vi fra den nationale og internationale forskning og hvad gor vi? ('The day-care center as an instrument to break the social heritage - what do we know from the national and international research and what do we do?). Arbejdspapir 8, Vidensopsamling om social arv. København: Socialforskningsinstituttet.

[20] Jensen, B. (2005). Kan daginstitutioner gфre en forskel? En undersøgelse af daginstitutioner og social arv ('Can daycare centers make a difference? A study of day care and social heritage'). København: Socialforskningsinstituttet.

[21] Jensen, B. et al. (2005). Kompetence- og metodeudvikling $i$ daginstitutioner - Om implementering af "ny" viden $i$ praksis. ('Competence and method development in day-care centers - About implementation of "new" knowledge in practice'). København: Danmarks Pædagogiske Universitetsforlag.

[22] Jensen, B. et al. (2006). Handlekompetencer $i$ padagogisk arbejde med socialt udsatte børn og unge indsats og effekt. ('Action competencies in educational work with socially disadvantaged children and young people - action and effect'). HPA-projektet. Samlet projektbeskrivelse. Juni 2006. Danmarks Pædagogiske Universitet.

[23] Jensen, B. et al. (2009). Handlekompetence $i$ padagogisk arbejde med socialt udsatte børn og unge indsats og effekt. ('Action competencies in educational work with socially disadvantaged children and young people - action and effect'). HPA-projektet. En sammenfatning. Danmarks Pædagogiske Universitets Forlag.

[24] Jensen, N.R., Petersen, K.E., \& Wind, A.K. (2012). Daginstitutionens betydning for udsatte børn og familier $i$ ghetto-lignende boligområder. ('The day-care institution's importance for socially vulnerable children and families in ghetto residential areas'). Rapport, Institut for Uddannelse og Pædagogik (DPU), Aarhus Universitet.

[25] Jensen, N.R., \& Petersen, K.E. (2012). Evolution of child protection and child welfare policies in Denmark. ERIS - Monograph on child protection.

[26] Jensen, S.Q., \& Christensen A.-D. (2012). 'Territorial stigmatisering og lokal autonomi'. ('Territorial stigmatisation and local autonomy'). Social Kritik, 130, 31-41.

[27] Jensen, B., Holm, A., Bremberg, S. (2013) Effectiveness of a Danish early year preschool preschool program - a randomized trail. International Journal of Educational Research 62 (2013) 115-128.

[28] Jensen, N.R., Petersen, K.E., \& Wind, A.K. (2014). Daginstitutioner $i$ udsatte boligområder - padagogisk udvikling $i$ arbejdet med udsatte børn og familier. Et forsknings- og udviklingsprojekt. ('Day-care institutions in socially deprived residential areas - pedagogical development in working with socially vulnerable children 
and families. A research and development project'). Rapport, Aarhus Universitet.

[29] Kaiser, A.P. et al. (2000). Parent-reported Behavioral Problems and Language delays in Boys and Girls Enrolled in Head-Start Classrooms. Behavioral Disorders, Nov. 2000/vol. 26(1), 26-41.

[30] Kleis, B. (2010). Livet i multietniske boligområder. Integration, rummelighed og konflikthåndtering. ('Life in multi ethnic areas. Integration, diversity and conflict management'). Statens Byggeforskningsinstitut, Aalborg Universitet.

[31] Larsen, T. S. (2009). De forsømte: Skitse til en socialvidenskabelig om relationerne mellem produktionen af forsфmte boligområder, kampe om det boligsociale integrationsarbejde, og den boligsociale integration. ('The dilapidated: Outline of a cociological analysis in terms of field of the relations between the production of dilapidated urban areas, the social struggles over the content, organization and execution of the social housing integration work'). Ph.d.-afhandling. Institut for Samfund og Globalisering, RUC.

[32] Lutz et al. (2002). Multidementional assessment of emotional and behavioral adjustment problems of lowincome preschool children: development and initial validation. Early Childhood Research Quaterly, 2002/Vol. 17(4), 338-355.

[33] Lyons-Ruth, K., \& Melnick, S. (2004). Does Response Effect of Mother-Infant Clinical Home Visiting on Aggressive Behaviour Problems in Kindergarten. Journal of the American Academy of Child \& Adolescent Psychiatry, 2004/vol. 43(6), 699-707.

[34] Ministeriet for Børn, Ligestilling, Integration og Sociale Forhold (2013). Lov om dag, fritids- og klubtilbud m.v. til børn og unge (dagtilbudsloven). ('Act on day, school and club facilities, etc. for children and adolescents (daycare Act)').

[35] Nordahl, T. et al. (2012). Kvalitet $i$ dagtilbuddet - set med børneøjne. En kortlagning af pilotprojektet: LPmodellen $i$ de kommunale dagtilbud. ('Day-care facility and quality - through the eyes of children. A mapping of the pilot project: the LP model in local day-care facilities'). Laboratorium for forskningsbaseret skoleudvikling og pædagogisk praksis. Aalborg Universitet. Forlaget DAFOLO.

[36] Nordenbo, S. E. et al. (2008). Forskningskortlagning ag forskningsvurdering af Skandinavisk forskning $i$ året 2006 i institutioner for de 0-5 årige ('Research mapping and research assessment of Scandinavian research in the year 2006 in institutions for the 0-6 year old'). Dansk Clearinghouse for Uddannelsesforskning, Danmarks Pædagogiske Universitetsforlag.

[37] Nordenbo, S.E. et al. (2010). Forskningskortlagning og forskervurdering af skandinavisk forskning $i$ året $2008 i$ institutioner for de 0-6 årige (førskolen) årige ('Research mapping and research assessment of Scandinavian research in the year 2008 in institutions for the 0-6 year old (preschool'). Dansk Clearinghouse for uddannelsesforskning.
Danmarks Pædagogiske Universitetsskole, Aarhus Universitet.

[38] Oldrup et al. (2010). Boligsociale indsatser rettet mod børn, unge og familier. En kortlagning. ('Social housing projects aimed at children, young people and families. A mapping.'). Forskningsafdelingen for børn og familie, SFI - Det Nationale Forskningscenter for Velfærd.

[39] Palludan, C. (2005). Børnehaven gфr en forskel. ('The kindergarten makes a difference'). København: Danmarks Pædagogiske Universitets Forlag.

[40] Petersen, K.E. (2008). Daginstitutioners betydning for udsatte børn - en forskningsoversigt. ('Day-care institutions' importance for socially vulnerable children - a research review'). København: Danmarks Pædagogiske Universitetsforlag.

[41] Petersen, K.E. (2009). Omsorg for socialt udsatte børn. En analyse af padagogers kompetencer og padagogiske arbejde med socialt udsatte børn $i$ daginstitutionen. ('Caring for socially disadvantaged children. An analysis of teachers' skills and educational work with socially disadvantaged children in day-care'). Ph.d.-afhandling. Institut for Pædagogik, DPU, Aarhus Universitet.

[42] Petersen, K.E. (2010). Viden om anbragte børn og unge $i$ dogntilbud. ('Knowledge of children and young people in residential care'). København: Socialpædagogernes Landsforbund.

[43] Petersen, K.E. (2011). Padagogisk arbejde med socialt udsatte børn $i$ børnehaven. ('Pedagogical work with socially vulnerable children in kindergarten'). København: Akademisk Forlag.

[44] Primavera, J. (2000). 'Enchancing Family Competence Through Literacy Activities.' Journal of Prevention \& Intervention in The Community, 2000, 20(12), $85-101$

[45] Raver, C.C. et al. (1999). 'Relations Between Effective Emotional Self-Regulation, Attentional Control, and Low-income Preschoolers' Social Competence with Peers.' Early Education and Development, July 1999/vol. 10(3), 333-350.

[46] Rutter, M. (1985). 'Resilience in the face of adversity. Protective factors and resistence to psychiatric disorder.' British Journal of Psychiatry, 147, 598-611.

[47] Rutter, M. (2000). Resilience reconsidered: Conceptual considerations, empirical findings, and policy implications, in: J.P. Shokoff \& S. J. Meisels (eds.), Handbook of early childhood intervention. Second Edition, 651-682. Cambridge: Cambridge University Press.

[48] Sammons et al. (2004). The effective provision of preschool education. Report on age 6 Assessment. Institute of Education. Department of London, Technical Paper 9.

[49] Schultz Jørgensen et al. (1993). Risikobørn, hvem er de, hvad gor vi? ('Children at risk, who are they, what do 
we do?'). Udarbejdet for det tværministerielle børneudvalg, dec. 1993.

[50] Social-, Børne- og Integrationsministeriet (2007, 2009), Lov om dag, fritids- og klubtilbud m.v. til børn og unge (dagtilbudsloven) ('Act on day, school and club facilities, etc. children and adolescents (daycare Act)'). Lov nr. 501.

[51] Socialministeriet (2004). Lov om aendring af lov om social service (padagogiske lareplaner $i$ dagtilbud til $b \phi r n$ ). ('Law amending the Law on Social Services (educational curricula in child day-care)').

[52] Sylvia et al. (2003). Assessing quality in the early years - early childhood environment rating scale. Trentham Books, Stoke on Trent, UK and Sterling, USA.

[53] Trocmé, N., \& Caunce, C. (1995). 'The Educational need of abused and neglected children: A review of literature.' Early Childhood Development and Care, vol.106, 101-135.

[54] Van Kuyk, J.J. (2001). Pyramid Educational Method for 3 to 6-yearold children: Theory and Research. Paper presented at the Annual Conference of the National Association for the Education of Young Children, National Institute for Early Childhood Professionel Development (10-13 June, Washington, DC, p. 1-26).

[55] Wright et al. (2000). 'School readiness of low-income children at risk for school failure.' Journal of Children \& Poverty, 2000/6(2), 99-117. 